\title{
生物模倣と自己組織化は，成形加工に何をもたらすか： 生物規範工学の構築に向けて
}

\section{1.はじめに：何故，今，生物模倣なのか？}

生物は長い進化の過程で, 様々な地球環境に適応してき た. ほ乳類の進化系統樹の極みである“ヒト”はさらに“進 化”をして「人間」となり，自然に働きかけて物やエネル ギー，そして情報を作り出す「人間の技術体系」を構築し てきた。やや極端な言い方をすると，産業革命や IT 革命 以来「人間の技術体系」は，「化石資源や原子力をエネル ギー源」とし，「鉄，アルミ，シリコン，そして希少元素」 を原料として，「リソグラフィ」を駆使してモノを作り， 情報や価値を生み出してきた。平成 23 年東北地方太平洋 沖地震」による東京電力福島第一原子力発電所の原子力事 故は，産業革命以来の「人間の技術体系」に内在する環境， 資源ならびにエネルギー問題を改めてクローズアップした.

一方, 人間以外の生物も, 自然に働きかけることで生命 活動を維持し種を保存している. 植物や動物は，「太陽光 や化学エネルギー」を用いて,「炭素を中心とする有機化 合物」を主として，「分子集合や自己組織化」によって, 場合によっては「時間」をかけながらモノを作る，「生物 の技術体系」とも言うべき仕組みを持っている，その結果， 「人間の技術体系」によって作られたモノとは，「違う生産 プロセス」でつくられ「違う作動原理」で動き「違う制御 方法」で調節されたシステムが構築されているのである(図1).

今世紀に入り，ヨーロッパ，とりわけドイッと英国に拉 いて, 自然史学を中心とする生物学とナノテクノロジーの 連携による「生物模倣技術（Biomimetics，アメリカでは Biomimicry)」と呼ばれる新たな研究潮流に注目が集まっ ている.「生物模倣技術」を用いることで, 蓮の葉の超撥 水性, ヤモリや昆虫の足の接着性, サx肌の流体抵抗低減 化, 蛾の眼の持つ無反射性, モルフォ蝶の鱗粉が放つ構造 色など, 生物表面に形成されるナノ・マイクロ構造に起因 する特異な機能を模倣して，テフロンを使わない撥水材料， 接着物質を使わない粘着テープ，スズ化合物を使わない船 底防污材料, 金属薄膜を使わない無反射フィルム, 色材を 用いない発色繊維などが開発されている (図 2).

さらに，今年 3 月にはドイツ政府の支援のもとベルリン において “International Industrial Convention on Biomi-

\footnotetext{
* Shimomura, Masatsugu

東北大学 原子分子材料科学高等研究機構

仙台市青葉区片平 2-1-1（９980-8577）

2011.5.18 受理
}

metics”が開催された。また経済・社会学的な観点から "Potentials and Trends in Biomimetics" (A. Gleich 他, Springer 2010）が出版され，生物多様性条約の国家戦略 として組織された “Biodiversity in Good Company” が Biomimeticsを重要課題に設定するなど, 産学連携, 異分 野連携が促進されている。米国に㧍いても，NYSERDA (New York State Energy Research and Development Authority）が Biomimicryをエネルギー戦略に取り入れ るなど，欧米において「生物模倣技術」が注目される背景 には,「生物の技術体系」が持つエネルギー, 資源ならび に環境問題に対する革新的な解決の可能性 (Innovation potentials）があるように思われる。「サステナビリティー」 や「グリーン・イノベーション」の課題は,「エネルギー をどうやって安全に効率よく創るのか?」，「効率的な省エ ネ型のモノ作りプロセスは?」,「エネルギー散逸を抑えて 効率的にモノを使うには?」という課題の解決である。「生 物の技術体系」は，それらの課題を解決することができる のであろうか.

\section{2.「生物の技術体系」のパラダイムはなにか}

昆虫や植物の体表面に形成されるナノ・マイクロ構造は 特徵的な機能を有しており, その形成過程と機能発現機構 は，工学的に設計・製造したものとは異なる規範（パラダ イム）に基づいている。「人間の技術体系」にイノベーショ ンをもたらすと期待される「生物の技術体系」のパラダイ

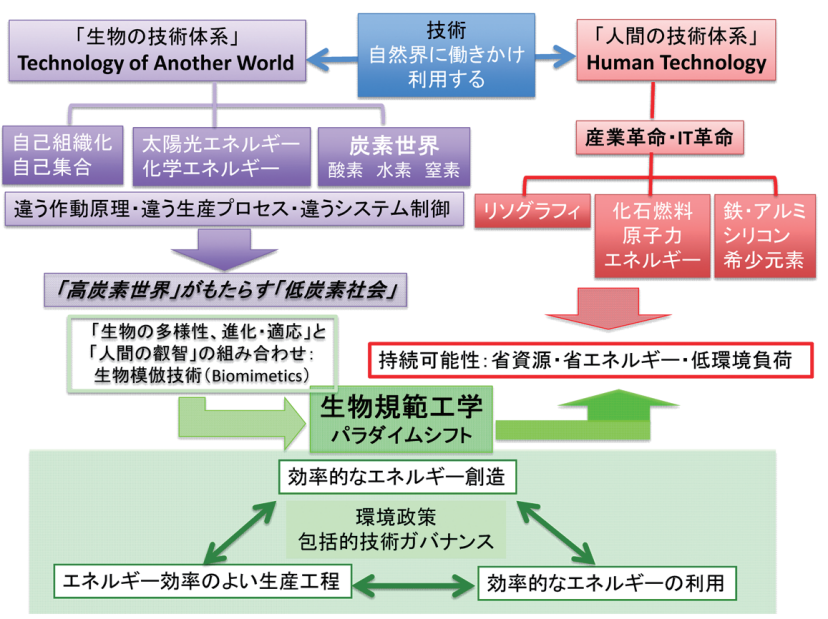

図 1 「人間の技術体系」と「生物の技術体系」 
ムとは，何なのか？「人間の技術体系」と「生物の技術体 系」の際だった違いを「作動原理」と「生産プロセス」の 違いを例に説明しよう。

ナガヒラタタマムシと呼ばれるオーストラリアに生息す る甲虫は, 数十キロ先の山火事を感知してそこに産卵する. 山火事の跡には捕食者がいないからだと考えられている. ボン大学動物学教室の H. Schmitz 博士らは, タマムシの 複眼の後ろに配列している球状の細胞群が, 高感度の赤外 線センサーとして働くことを明らかにした．球状細胞は硬 いクチクラの外壁で覆われており, その内部は細い水路が 三次元に張り巡らされた“カナル構造”になっている. 液 体に満たされたカナル構造の底には, メカノセンサーとし て作用する感覚毛があり神経系につながっている．硬いク チクラの殼に閉じ达められた狭い空間で熱膨張した液体は 感覚毛を押すことで, 外部の “熱情報” は効果的に“力学
情報”に変換されて神経系に伝達される。「生物の技術体 系」では，閉じ込められた空間をうまく利用して，熱エネ ルギーから力学エネルギーへの変換によって情報を得てい るのである。一方，「人間の技術体系」ではどうするであ ろうか? 例えば， GaAs などの化合物半導体の量子効果を 利用した赤外線センサーが開発されている. 二つの技術体 系では,「作動原理」が異なるのである. 生物学者と MEMS 研究者の共同研究によって, 生物模倣によってもたらされ た新しい「作動原理」で作動する赤外線センサーが開発さ れた. センサーの構造は極めて簡単で, 狭い空間に閉じ込 められた液体の熱膨張を薄膜コンデンサーの容量変化とし て検出するのである（図 3 ）。

英国バース大学の J. Vincent 教授は，TRIZ と呼ばれる 問題解決策を用いて，生物につくられるモノと人間が工業 的に作るモノの要素の解析を行った。 その結果, 生物は「情
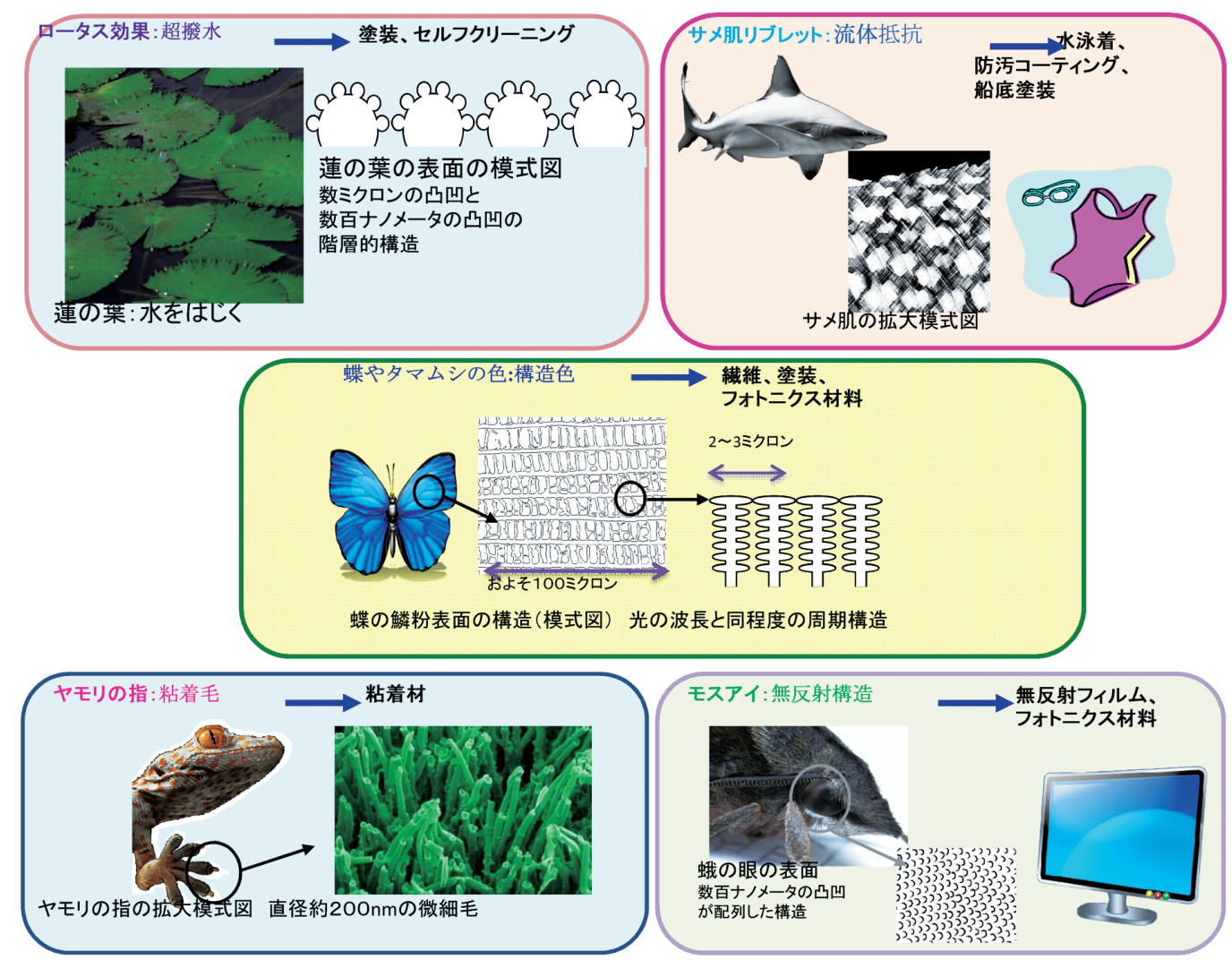

図 2 「生物模倣」技術の例 ${ }^{1)}$
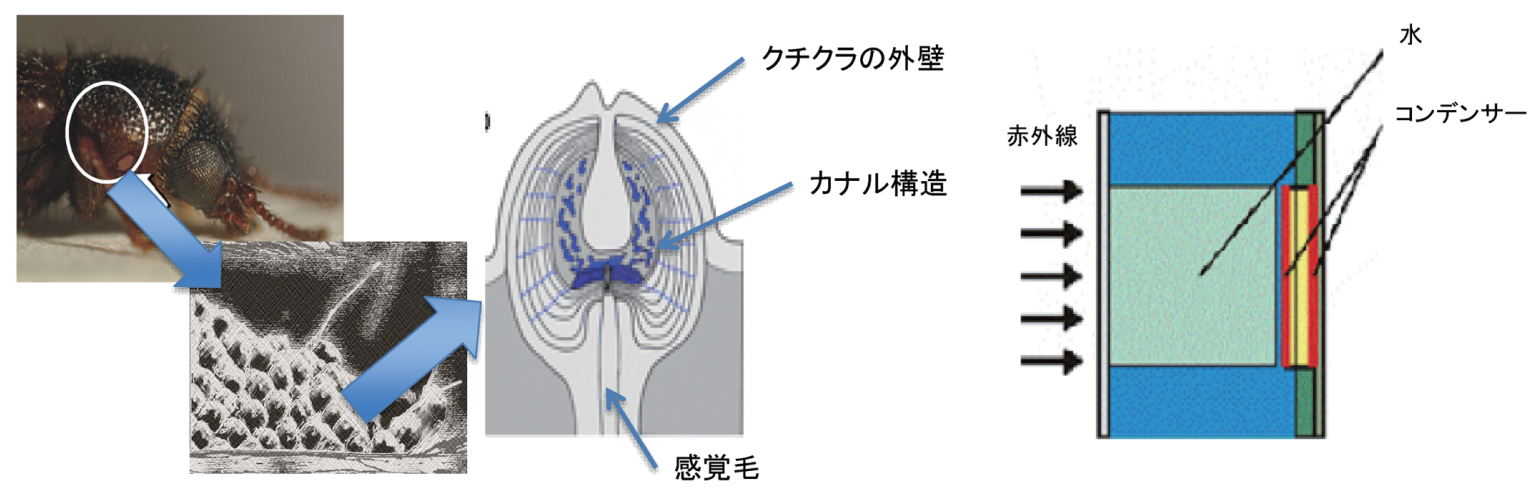

図 3 昆虫に学ぶ赤外線センサー ${ }^{2)}$ 
報」や「空間」，「構造」を有効に利用しているのに対し， 工業技術は「エネルギー」や「物質」に多くを依存してい る.つまり, 生物は主として炭素や酸素, 窒素を使って核 酸やタンパク質のように「情報」を有する分子を作り，そ れらは細胞や組織などの「構造」や「空間」を階層的に形 成する。それには「時間」も必要である。一方，人間には， ガリウムやヒ素などの希少元素とされる「物質」なども使 い, 多量の「エネルギー」を必要とするリソグラフィなど の工程を駆使して, 半導体チップやデバイスを短時間で製 造する (図 4).

生物の構造形成のおおもとになる過程は, 遺伝子によっ てプログラムされた複雑な化学反応プロセスの組み合わせ である．遺伝子によってつくられた脂質分子やタンパク質 は，自己集合によって高次の構造体を作りあげていく．ま た，生物の表面構造の多くは，細胞の分泌物であったり， 死骸であったりする。どのような分泌物をどの夕イミング で細胞の外に出すのかは遺伝子にプログラムされているも のの, 一旦細胞から分泌された物質が構造を形成するプロ セスは，例えば液晶分子が自発的にナノ・マイクロ構造を 形成するように，その時の環境に決定される物理化学に支 配されたプロセスである。つまり生物は, 分子の自己集合 や分子集合体の自己組織化などを生物学的環境だけでなく, 非生物学的環境においても有効に利用していると考えられる.

生物模倣材料開発においては, 多くの場合, まず, 電子 線描画やリソグラフィなどトップダウン型ナノテクノロ ジーによって作製された “初期モデル”によって原理確認 が行われる，実用化に向けたステージでは，効率よくかつ 安価に製造することが求められることになる.ナノインプ リントなどの金型技術, インクジェットなどのパターン化 技術, 結晶成長技術, ブロックコポリマー・リソグラフィー やマイクロ・コンタクト・プリンティングなどの自己集合 現象の利用, 散逸構造などの自己組織化現象の利用など, これまでにナノテクノロジーで使用されている様々な製造 技術を総合的に検討し, 生物型の生産技術を模索すること は可能であろう. 化学反応プロセスだけで構造化材料を作
製することは困難であるが，将来的には自己集合や，自己 組織化のような物理プロセスを組み合わせることで, 高次 に階層化された材料を創ることは可能である。ここに，人 類の培ってきた䍉智を使うべきであり，新しい成形加工技 術が生まれる。

\section{3．自己組織化による生物模倣低摩擦表面の作製}

「生物の技術体系」のパラダイムの特徴である，「作動原 理」と「生産プロセス」の違いを象徴する例として, ここ では，自己組織化技術と生物模倣デザインを基にした低摩 擦表面の作製の試みを紹介する。

摩擦は，生体においても人工物においても常におこるも のであり，時としてエネルギー損失の原因であるものの， 摩擦がなければ止まることも歩くこともできない. 摩擦は, 物体の “動作”における重要な要因なのである。摩擦の制 御は，“動作”をともなうあらゆる “装置” (機械, 内燃機 関，モーター，人工関節，など）の特性と機能発現に本質 的に関わっているだけでなく，「エネルギー散逸を抑えて 効率的にモノを使うには?」という課題の解決にも直結し ている．近年，機械工学の分野では，本来は平滑である金 属表面にクロスハッチなどの “キズ”を導入することで, “潤滑剂溜まり”が形成され，摩擦低減や焼き付け防止に 有効であることが明らかにされつつある. しかし，工業的 手法によるテクスチャー化には，レーザー・アブレーショ ンなどの大きなエネルギー消費を伴うトップダウン型ナ ノ・マイクロ加工が主として用いられているのが現状である.

一方, 昆虫や爬虫類の体表面には, 生物が自ら作り出し ている微細構造があり, その微細構造が乾燥した砂漠や濡 れた葉の表面などの様々な接地環境に適応できる摩擦特性 をもつ. Kiel 大学の動物学者である S. Gorb 教授らは, 昆 虫や植物の表面トライボロジーについて系統的な研究を展 開している.たとえば,キリギリス (Tettigonia viridissima) の足先には 4 $5 \mu \mathrm{m}$ の 6 角形のパターンがタイル状に配 列している. Gorbらは, この構造がどのようなトライボ ロジー特性を有するのかを調べるために，マイクロ加工技

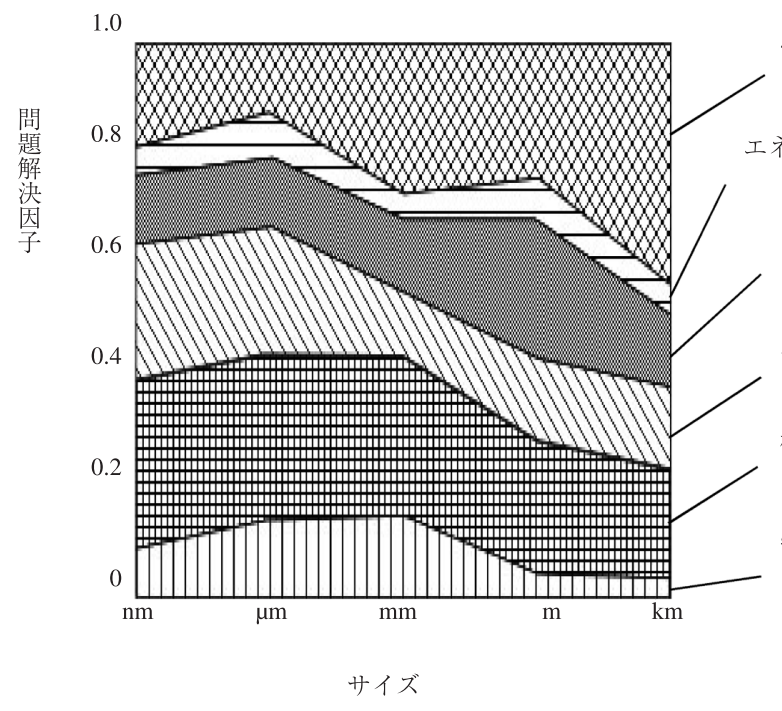

生物

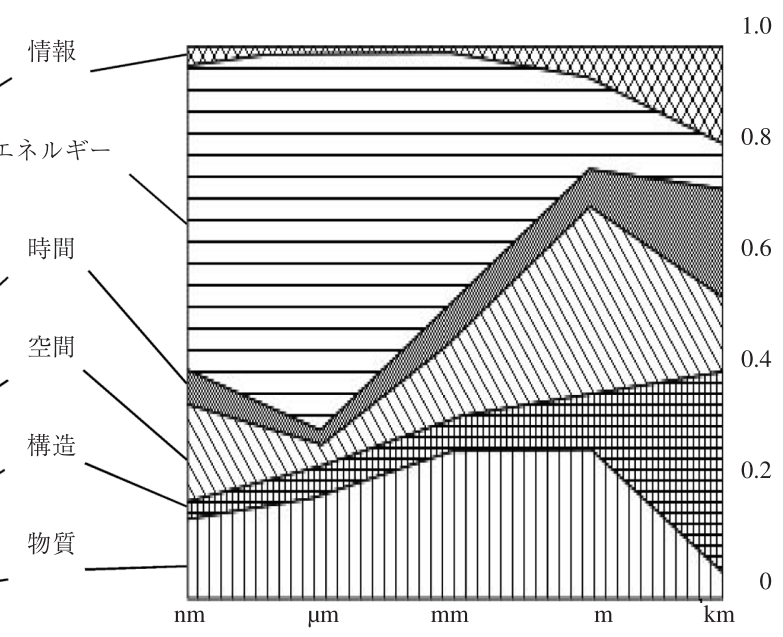

サイズ

図 4 生物と人間のモノつくり比較 
術を用いてシリコンゴム表面に微細パターンを作製した足 先のモデルを作り平滑な固体基板上での摩擦係数を測定し た.表面が乾いた固体基板の上では, シリコン表面にパター ンが無く平滑な面を持つ足のモデルでは基板面上で間欠的 な，いわゆる「スティック・スリップ運動」をするのに対 し, 微細パターンを持つモデル足ではスムーズな運動性を

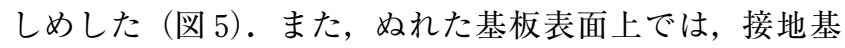
板表面に対する微細パターン化足モデルの吸着力はパター ンの無いモデルよりも大きく, 横滑り現象 (hydroplaning) を防ぐことで安定な運動性が保証されていることが示唆さ れた。車の夕イヤに刻まれた溝と同じ効果が，バッタの足 先でも見られるのである.

爬虫類の体表面が低い摩擦係数を有する場合がある. 北 アフリカや南西アジアの砂漠に生息する有鱗目スキンク科 のトカゲ (Scincus scincus) は，砂の中に潜り泳ぐように 移動することからサンドフィッシュ（Sandfish）と呼ばれ ている. ベルリン工科大学の I. Rechenberg 教授は, サン ドフィッシュの皮膚が磨かれたスチールや平滑なガラス, テフロンや高密度ナイロンなどの表面よりも低い摩擦係数 を示し，砂でこすれてもほとんど摩耗しないことを見いだ した。ケラチンを主成分とするサンドフィッシュの鱗の表 面にはミクロな微細構造があり, この構造が特異なトライ ボロジーを発現している。 サンドフィッシュの鱗には, 数 $\mu \mathrm{m}$ の間隔で並んだサブマイクロメータの高さの長い尾根 状の “敷居” (nanothresholds) がある。この “敷居”と砂 粒間の摩擦帯電で発生した静電気が, 鱗と砂粒の間の斥力 を生み出すことによって摩擦が低減される可能性を示唆し ている。

一方, トカゲの捕食者である蛇の表皮も低摩擦表面であ り, バイオミメティクスの研究対象になっている. Gorb 教授らは, Schmitz 博士の共同研究者でもあるボン大学動 物学教室の H. Bleckmann 教授との共同研究において, ア マゾンに生息する Boa と呼ばれる蛇 (Squamata, Boidae) の表皮が，孔径数マイクロメートルの網目状構造で覆われ ていることを見いだした，その摩擦係数は平滑な金属表面 よりも小さく，さらに興味あることに，網の目の形状には 若干の異方性があり, 摩擦係数にも異方性が反映されている

我々は，高分子の湿式製膜時に起こる自己組織化現象を 利用することで, 様々なナノ・マイクロ構造を省エネル ギープロセスで作製できることを見いだした，とりわけ， 高湿度条件下で湿式製膜した高分子フィルムの表面には, 蛇の体表面に形成される網目状構造に類似したミクロ構造 が形成される.この構造は，製膜過程で高分子溶液表面に 結露した水滴が自発的に規則集合し，それを鋳型として高
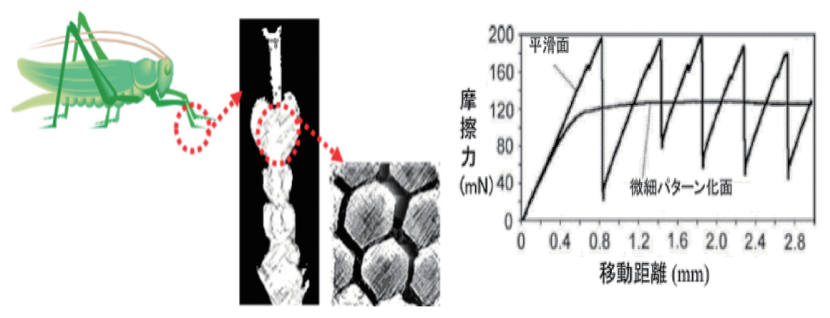

図 5 キリギリスの足の微細構造と摩擦挙動 ${ }^{4)}$
分子フィルムに細孔が穿たれる現象を用いることで形成さ れるものであり, 自己組織化プロセスによる形成加工法で ある（図 6)。そこで, 生物模倣によるテクスチャー・デ ザインと, 省エネルギープロセスである自己組織化を駆使 したナノ・マイクロ加工技術を組み合わせることで, 金属 表面の新しい微細加工方法を開発し，テクスチャリングを 施すことによる固体潤滑機構の理論的解明とともに, 潤滑 剂存在下での低摩擦化, 焼き付け防止などの実用的展開を 図ることにした。

潤滑剤の使用は摩擦低減の一般的な手法である。エンジ ンやトランスミッションは高速で摩擦しているため, 潤滑 油の使用は必須である。しかし，それら高速運動する摩擦 面では潤滑油の部品への供給が十分に追随できるとは限ら ず，潤滑剂供給の欠如は摩擦による温度上昇とそれに伴う 「焼き付き」を起す，特に最近は，車の低燃費化のため低 粘度潤滑油が用いられる傾向にあり，摩擦面の油膜厚が薄 くなることで「焼き付き」現象が助長される傾向にある. そこで, 部品表面を微細構造化（テクスチャー化）するこ とによって油溜めを形成し, 潤滑油の保持と安定な供給を 罒ることで摩擦を低減化しようとする試みがなされている.

ここでは，図 6 で作製した多孔質高分子フィルム（蜂の 巣様の形態なのでハニカムフィルムと呼んでいる。厳密に は蜂の巣のように個々の細孔は孤立してはなく, 連通して いる.）を金属基板のウェットエッチングマスクとして, 金属表面にテクスチャーを導入することにした：まず，ポ リメチルメタクリレート（PMMA） と結露水滴の安定化 剂として作用する両親媒性ポリアクリルアミドの共重合体 からなるクロロホルム溶液を調整し, 固体基板上に高湿度 下で塗布製膜しハニカムフィルムを得た。 ハニカムフィル ムの細孔面にポリビニルアルコール（PVA）水溶液をス ピンコートし, 細孔面を鉄基板に貼付けて乾燥することで, PVA を“糊”としてハニカムフィルムの細孔面を鉄表面 に密着した. 乾燥後, 鉄基板上に貼付けたハニカムフィル ムの底面を粘着テープで剥がし取り, 軽い水洗により余分 な PVA を除いた後に, 再度アニーリングすることでハニ カムマスクを鉄基板上に完全に融着させた。その後，硝酸 とエタノールの混合溶液に浸漬して鉄基板のエッチングを 行った.エッチングの深さは浸漬工程時間を変えることに より制御することができた. エッチング後に, 水とアセト ンの混合溶媒に浸漬, 超音波処理することでマスクを除去 した（図 7). ハニカムフィルム，鉄基板上に固定された エッチングマスク，エッチング後の鉄表面の SEM 像と， 鉄表面に形成された窪み（ディンプル）状テクスチャーの

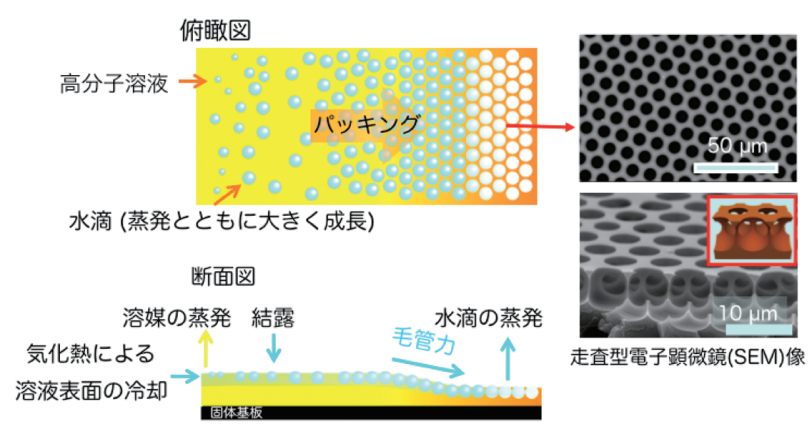

図 6 自己組織化によるハニカム高分子フィルムの作製 

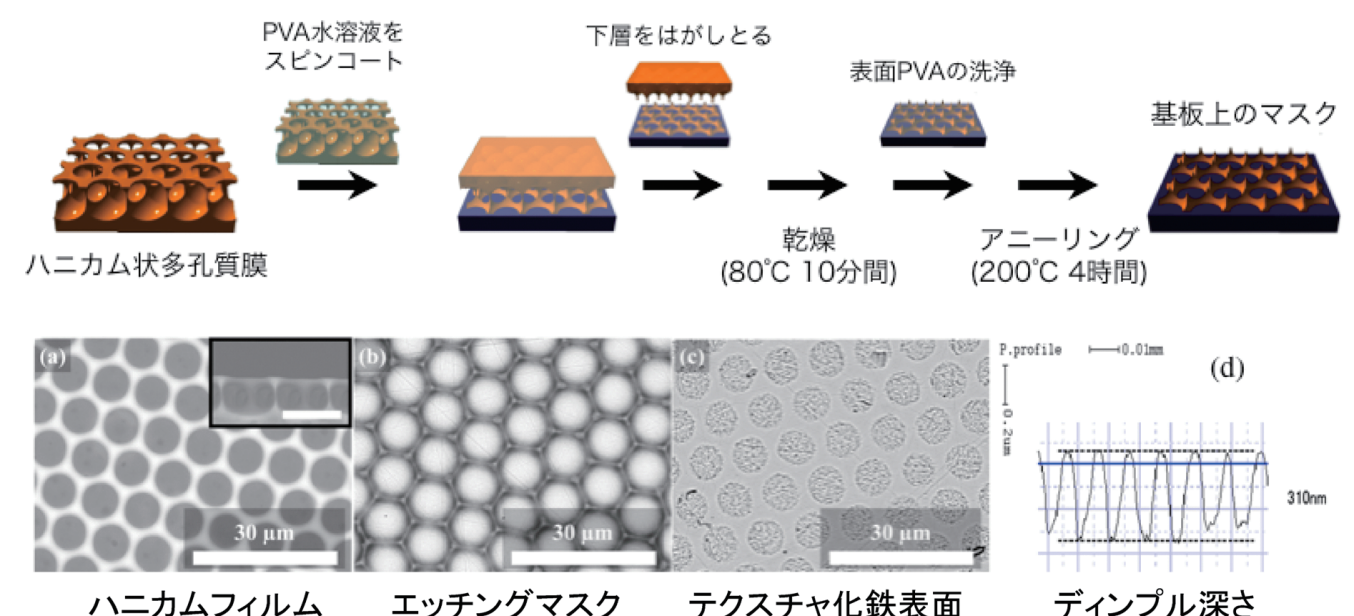

図 7 ハニカムマスクによる金属表面のテクスチャリング5)

（1）摩擦係数と焼き付け荷重

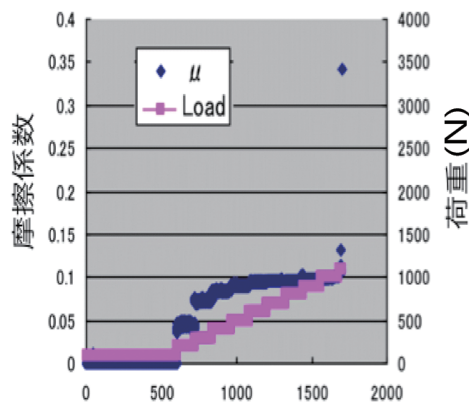

時間 (秒)
(2) 摩擦係数とディンプル深さ

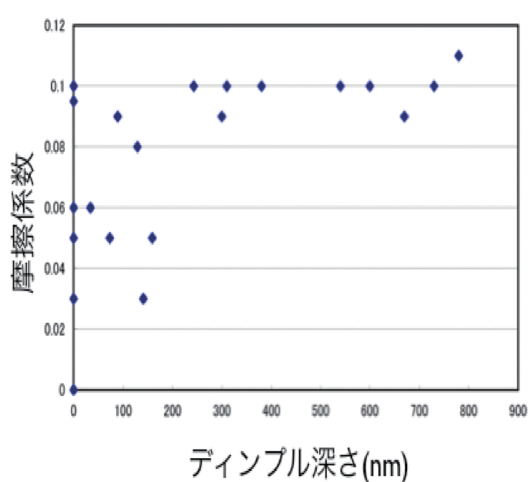

（3）焼き付き荷重とディンプル深さ

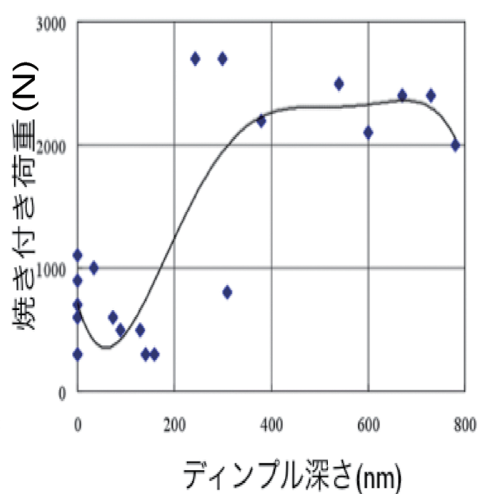

図 8 焼き付けにおよぼす金属表面テクスチャの効果 ${ }^{5)}$

深さプロファイルを示す．鉄基板上に固定されたエッチン グマスクでは, ハニカムフィルムが有している空孔の周期 的配列が維持されており, さらに空孔部位では鉄基板が露 出している. エッチングマスクの空孔配列に対応して周期 的にディンプルが形成されており, さらに化学的なエッチ ング加工の特徴として，ディンプルの縁に“バリ”がない ことが確認できる，機械加工やレーザー・アブレーション では“バリ”が形成されることがあり，摩擦の原因になる。

リングオンプレート型摩耗試験を用いて, 鉄基板上で荷 重かけながらリングを高速回転させ，摩擦係数が急激に上 昇する荷重から「焼付き荷重」を求めた。潤滑油はエンジ ン油を用い, 試験回転数 $500 \mathrm{rpm}$ で, 最初の 10 分間は荷 重 $100 \mathrm{~N}$, その後 2 分毎に荷重を上げた. 図 8 に代表的な 試験結果（ディンプル処理を施さない鉄表面）を示す。こ の場合, 摩擦係数の急上昇から, 焼き付き荷重が $1100 \mathrm{~N}$ であると見つもられる.ディンプル深さが浅い場合には摩 擦係数は安定しないが, $200 \mathrm{~nm}$ 以上の深さになると 0.1 程度の值で安定になる傾向が明確に確認できた. ディンプ ルが $200 \mathrm{~nm}$ よりも梁くなると焼き付き荷重も高くなり, 一定になる傾向がみられた. 焼き付きに対して十分な油量 がディンプルから摩擦面に供給されるためだと考えられる. 自己組織化プロセスによって簡便に作製した高分子マスク を用いることで, 昆虫の足に見られるような微細な構造を
金属表面に導入することができ，さらには“潤滑剤溜まり” として摩擦係数の低下と焼き付き荷重の増加に有効である ことを示すことができた。

\section{4.おわりに：パラダイムシフト＝生物規範工学の構 築に向けて}

凸凹構造しているのに，摩擦係数が小さい．凸凹構造が あるので，濡れた葉の上に留まることができる．蛾の眼の 持つ無反射性から銘々された「モスアイ構造」も，凸凹構 造である. 撥水性に富む蓮の葉の表面も凸凹構造である. モスアイ構造は蛾だけではなく多くの昆虫に見られており， 蚊のように小さな昆虫では複眼が示す撥水性によって「雨 に濡れて溺れる危険」から身を守っていると考えられてい る. 表面ナノ・マイクロ構造がもたらす撥水性は, セミの 羽にも見られるが，七ミの羽は透明である。透明であるこ とは目立たないことを意味する。生物の表面構造が有する 多機能性（撥水性, セルフクリーニング性, 無反射性, 透 明性など）を模倣し利用することで太陽電池の性能向上も 期待されている.このように, 生物表面の多機能性の背景 には, 1 つの構造が 2 つ上の機能を果たす, 長い進化に よって培われた「省エネ設計」とも思える設計思想が隠れ ている．新規材料の設計においては，「省エネ設計」の観 点から生物の構造や機能や行動を見直す必要がある. 生物 
は，壮大な進化と適応の実験において，適用によって多様 性を示しながらも, 一方では, 限られたナノ・マイクロ構 造体から多様な機能を発現させる巧妙な仕組みを持つに 至ったのではないだろうか.

生物が有するナノ・マイクロ構造とそれらがもたらす機 能発現との相関に関する知見を収集することは, 生物学と くに形態学や発生学に扔ける大きな研究課題の一つである. さらに, 生物学者の発見を材料科学者が原理を確認して人 工系で再現, 再度, その結果を生物学者にフィードバック することが重要であり,この構図はヨーロッパに扔ける生 物模做研究の成功例に見て取ることができる. 基礎科学と 応用科学との橋渡しと異分野連携により, 自然史学の資源 であるインベントリーと呼ばれる生物標本に工学的な価值 をもたらすことができるのである。これにより「生物の技 術体系」と人間の瑴智を組み合わせた新しい技術体系とし ての「生物規範工学」の創成が期待される.「人間の技術
体系」が内在した現代的な課題である，エネルギー，環境， そして資源問題の解決をもたらすパラダイムのシフトであ り, イノベーションの鍵を持っているのかもしれない.

参 考 文 献

1) 下村政嗣：科学技術動向，No.110，9 (2010)

2 ) Schmitz, H., Mürtz, M. and Bleckmann, H. : Nature, 386 (6627), 773 (1997)

3 ) Vincent, J. F. V. , Bogatyreva, O. A., Bogatyrev, N. R., Bowyer, A. and Pahl, A. K. : J. R. Soc. Interface., 3 (9), 471(2006)

4) Varenberg, M. and Gorb, S. N. : Adv. Mater., 21 (4), $483(2009)$

5 ）鈴木厚，海道昌孝，平井悠司，藪浩，下村政嗣：機能 材料, 30, 29(2010)

\section{賛助会員の皆様へ \\ 「製品・技術紹介」へご投稿下さい}

「成形加工」誌には，「製品・技術紹介」のコーナーを設けています.

「製品・技術紹介」はプラスチック成形加工学会の賛助会員が自社の製品・技術を広く会員に アピールするための記事で，詳細は以下のとおりです.

1. 賛助会員企業の開発した装置・機械・材料等，各種製品と技術を資料・図表・写真等によ り紹介するもの.

2. 賛助会員企業に属する個人（または複数名）の記名入り記事とし, 長さは刷上がり 1 頁と する（図表を含み 2300 字程度，原稿 1 頁当たり 26 字 $\times 27$ 行 $=702$ 文字で作成）.

3. 掲載料は無料（ただしカラー印刷の場合は実費負担）.

この「製品・技術紹介」への投稿を，是非ご検討下さい.

「製品・技術紹介」は，投稿順（抜閲後）に随時掲載しております。記事のスタイル，内容等 につきましてはすでに掲載されている幾つかの記事をご参照下さい.

「成形加工」編集委員長 梶原稔尚 